\title{
Cadmium Content of South African Table Wines
}

\author{
W. ZEEMAN and C. S. DU PLESSIS \\ Oenological and Viticultural Research Institute, Private Bag X5026 Stellenbosch, 7600
}

\begin{abstract}
Red and white South African table wines from the major wine producing districts were analysed for cadmium content. Only three wines had a slightly higher concentration than $0,010 \mathrm{mg} / \ell$. The average cadmium concentration was $0,003 \mathrm{mg} / \ell$, and no relationship between cadmium content and origin could be determined.
\end{abstract}

In studies on the toxicity of specific heavy metals in foodstuffs much emphasis has been placed upon cadmium (Kloke, 1973). During the most recent meeting of the "Sub-commission for Conventional Methods for Analysis and Evaluation of Wine Quality" of the OIV, a study on the cadmium concentration in wines by member countries was accorded the highest priority. Several relevant studies have been reported (Bergner, Lang \& Ackermann, 1972; Bielig, Dreyer \& Treptow, 1975; Mack, 1975).

It has been found that cadmium can be taken up by the vine from fertilizers or from soil contaminated by diesel engine exhaust gases near highways (Bergner et al., 1972, Kloke, 1973; Gärtel, 1977). Furthermore, cadmium containing metal alloys used in cellar equipment with which grape juice and wines come into contact during processing, can contribute to excessive cadmium concentrations in wines (Bielig et al., 1975; Raposo, 1977).

The commission for the Codex Alimentarius recommended in its document CAC/FAL 3-1976, a temporary acceptable weekly intake of $0,0067-0,0083 \mathrm{mg}$ cadmium $/ \mathrm{kg}$ body mass. The World Health Organisation has to date not yet recommended an acceptable weekly intake of cadmium but is at present investigating this matter. Their findings will in all probability serve as guide-lines in a recommendation by the OIV of acceptable cadmium concentrations in wines. Because of the importance of this component a study was undertaken to determine the concentrations of cadmium in South African table wines.

\section{MATERIALS AND METHODS}

Table wines submitted to the Government Wine and Spirit Board for certification of origin, cultivar or year of harvest were used. One hundred and thirty nine samples (cf Table 1) were randomly drawn from the wines of eleven wine producing regions.

The wines were analysed by atomic absorption spectrophotometry according to the method of Anders \& Hailer (1976). A digital integrator was incorporated to cope with the lower readings, which could not be determined sufficiently accurately from strip chart recordings. Quantification was carried out by the addition method (Willard, Merrit \& Dean, 1965). Standard deviation between duplicates was $\pm 0,00031 \mathrm{mg} / \ell$ with the average concentration at $0,0034 \mathrm{mg} / \ell$.

\section{RESULTS AND DISCUSSION}

The distribution of the cadmium content of the samples in concentration ranges is given in Table 1. Only 3 samples exceeded $0,010 \mathrm{mg} / \ell$, of which two were white wines $(0,011$ and $0,015 \mathrm{mg} / \ell)$, and one a red wine $(0,015$ $\mathrm{mg} / \ell)$. The wines came from different cellars and regions. Furthermore, other wines from the same cellars all contained considerably less cadmium $(0,001-0,007 \mathrm{mg} / \ell)$. As a further example of intra-cellar fluctuation of cadmium content in wines, the white wine sample showing a concentration of $0,015 \mathrm{mg} / \ell$ serves as a case in point. Another wine made from grapes from the same vineyard had a cadmium concentration of only $0,001 \mathrm{mg} / \ell$. The indications were that the higher cadmium concentrations in wines were due rather to cadmium contamination in the cellar, than to carry-over from high concentrations in grapes.

TABLE 1

Cadmium content of white and red table wines*

\begin{tabular}{|c|c|c|c|c|c|}
\hline \multirow{2}{*}{ Wine Type } & \multicolumn{5}{|c|}{ Concentration groups $(\mathrm{mg} / \ell)$} \\
\hline & $<0,001$ & $\begin{array}{l}0,001- \\
0,005\end{array}$ & $\begin{array}{c}>0,005- \\
0,010\end{array}$ & $>0,010$ & Total \\
\hline $\begin{array}{l}\text { White } \\
\text { No. of samples ..... } \\
\% \text { of Samples ..... } \\
\text { Red } \\
\text { No. of Samples .... } \\
\% \text { of Samples . . . . } \\
\text { Total (Red \& White) } \\
\text { No. of Samples .... } \\
\% \text { of Total ....... }\end{array}$ & $\begin{array}{l}12 \\
17,4 \\
14 \\
20,0 \\
\\
26 \\
18,7\end{array}$ & $\begin{array}{l}43 \\
62,3 \\
45 \\
64,2 \\
88 \\
63,3\end{array}$ & $\begin{array}{l}12 \\
17,4 \\
10 \\
14,3 \\
\\
22 \\
15,8\end{array}$ & $\begin{array}{l}2 \\
2,9 \\
1 \\
1,4 \\
3 \\
2,2\end{array}$ & $\begin{array}{l}69 \\
- \\
70 \\
-\end{array}$ \\
\hline
\end{tabular}

*The average cadmium concentration of all the wines is $0,003 \mathrm{mg} / \ell$.

On a regional basis, wine cadmium concentrations showed no clear relationships with the origin of the grapes. Disregarding the three wines with cadmium concentrations in excess of $0,01 \mathrm{mg} / \ell$, concentrations in each region generally ranged between traces and $0,006 \mathrm{mg} / \ell$, with odd samples up to $0,009 \mathrm{mg} / \ell$. Furthermore, little difference in the distribution of the number of samples in the cadmium concentration ranges appears between red and white wines (Table 1). These findings are in general agreement with those of Bergner et al. (1972), who found no relationship between either cultivar or region and cadmium concentrations in German wines.

Bieber (1974) reported that in 198 German wines the maximum, minimum and average cadmium concentrations were $0,014,0,001$ and $0,002 \mathrm{mg} / \ell$ respectively. Similarly Daratsianos \& Mavrikos (1975) reported values of 0,010, 0,001 and 0,004 respectively in 100 Greek wines. Cabanis \& Cayrol (1977) reported values of 0,022, 0,003 and 0,009 respectively in 57 French wines. From the results reported in Table 1 it will be noted that the cadmium concentrations in South African wines are in general agreement with these values. 


\section{CONCLUSION}

The cadmium concentrations of red and white South African table wines have been shown to be in general conformity with relevant wines of other wine producing countries. At present the cadmium concentrations are below the temporary acceptable weekly intake specified by the Codex Alimentarius.

On the basis of published work and data presented in this study, a value not exceeding $0,010 \mathrm{mg} / \ell$ would at this stage appear to be a reasonable upper acceptable limit in wines. Evidence has been presented indicating that some of the wines analysed had higher cadmium values, which were in all probability due to the uptake of this metal during wine processing. The serious light in which cadmium in wines is viewed, makes it imperative that wine makers take all precautions with respect to chemicals and equipment used in order to keep concentrations as low as possible.

\section{REFERENCES}

ANDERS, U. \& HAILER, G., 1976. The substoichiometric extraction system MIBK/APDC and its application to the direct determination of $\mathrm{Pb}$ and $\mathrm{Cd}$ in wine. Z. Analyt. Chem. 278, 203-206.
BERGNER, K. G., LANG, B. \& ACKERMANN, H., 1972. Zum Cadmiumgehalt deutscher Weine. Mitt. Klosterneuberg. 22, 101-105.

BIEBER, H., 1974. Teneurs en plomb et en cadmium des mouts et des vins provenant du vignoble de Franconie. FV. 480. Report submitted to OIV.

BIELIG, H. J., DREYER, HEIDEMARIE \& TREPTOW, H., 1975. Beitrag zur Analytik des Schwermetallgehaltes von Fruchtsäften. Flüss. Obst. 42, 369-375.

CABANIS, J. C. \& CAYROL, M., 1977. Le cadmium les vins du Midi de la France. FV. 636. Report submitted to OIV.

DARATSIANOS, J. \& MAVRIKOS, P., 1975. Le lithium et le cadmium dans les vins Grecs. FV. 555. Report submitted to OIV.

GÄRTEL, C. W., 1977. Work report; 18th Meeting of OIV Sub-commission for conventional methods of analysis and evaluation of wines. Paris.

KLOKE, A., 1973. Schwermetalle in Nahrungs- und Futterpflanzen Dt. LebensmittRdsch. 69, 45-49.

MACK, D., 1975. Blei- und Cadmiumgehalte von Wein, Weinmost und Weintrauben aus der Umgebung einer Immissionsquelle. Dt. LebensmittRdsch. 71, 431-432.

RAPOSO, M. R., 1977. Work report, 18th Meeting at OIV Sub-commission for conventional methods of analysis and evaluation of wines. Paris.

WILLARD, H. H., MERRIT, JNR., L. L. \& DEAN, J. A., 1965. Instrumental methods of analyses. 4th ed. Princeton N.J. D. van Nostrand Co. Inc. 